\title{
Proses Pembentukkan Gairaigo dalam Buku Teks Minna no Nihongo: Kajian Morfologi
}

Damai Yani

Universitas Negeri padang

damai.yani@yahoo.com

\begin{abstract}
Abstrak
Gairaigo adalah kosakata bahasa Jepang yang ditulis dengan huruf katakana. Gairaigo merupakan kosakata yang special, meskipun berasal dari bahasa asing tetapi jika digunakan dalam bahasa Jepang harus sesuai dengan aturan pengucapan dan penulisan bahasa Jepang. Data penelitian ini diambil dari buku teks minna no nihongo shokyu 1. Terdapat 97 gairaigo di dalam buku teks minna no nihongo shokyu 1 , tapi makalah ini hanya menjelaskan pembentukkan gairaigo. Ada tiga proses morfologis dari gairaigo yang ditemukan dalam penelitian ini. Pertama, gairaigo yang terbentuk melalui proses afiksasi, kedua, gairaigo yang terbentuk melalui proses penggabungan dan ketiga, gairaigo yang terbentuk melalui proses pemendekkan. Pada prosespemendekkan terdapat di dalamnya proses pemenggalan dan konstraksi. Untuk menjelaskan proses morfologi dari gairaigo digunakan teori dari sutedi (2003) dan tsujimura (2000). Penelitian ini merupakan penelitian kualitatif dengan metode deskriptif.
\end{abstract}

Keywords : Gairaigo, proses morfologis, borrowing

\section{Abstract}

Gairaigo is a Japanese vocabulary written in katakana letters. Gairaigo is a special vocabulary, although the words derived from a foreign language but if they are used in Japanese language, they must be appropriated with the rules in the Japanese pronunciation and writing procedures. The data in this research taken from minna no nihongo shokyu I textbook. There are 97 gairaigo in the minna 
no nihongo shokyu I, but this paper only explains the formation of gairago. There are three morphological process of gairaigo that can be found in this research. First, gairaigo which is formed by affixation process. Second, gairaigo which is formed by compounding process and third gairaigo which is formed by abbreviation process. Clipping and contraction (karikomi) are included in the abbreviation process. To explain the morphological process of gairaigo, this research used theory by sutedi and tsujimura. This research is qualitative research with descriptive methode.

Keywords: Gairaigo, morphological process, borrowing

\section{Pendahuluan}

Bahasa digunakan untuk menyampaikan informasi baik secara lisan maupun tulisan, sehingga suatu bahasa sering bertemu dan berdampingan dengan bahasa asing lainnya. Bahasa itu bersifat dinamis, yaitu dapat mengalami perubahan sewaktu-waktu. "Bahasa mengalami dua macam perubahan yaitu perubahan internal dan perubahan eksternal. Perubahan internal terjadi dari dalam bahasa itu sendiri seperti berubahnya sistem fonologi, morfologi atau sintaksis. Sedangkan perubahan eksternal terjadi sebagai akibat adanya pengaruh dari luar seperti peminjaman atau penyerapan kosakata, penambahan fonem dari bahasa lain dan sebagainya."(Chaer \& Agustina, 1993:184). Pada dasarnya setiap bahasa di dunia memiliki karakteristik masing-masing yang membuatnya berbeda dengan bahasa lain. Sehingga, walaupun bahasa tersebut menyerap katakata dari bahasa lain, sifat khas dari bahasa tersebut akan tetap terlihat.

Sejalan dengan perkembangan zaman, terutama perkembangan teknologi informasi yang terus meluas ke seluruh penjuru dunia, membuat semakin banyak apresiasi orang terhadap bahasa asing terutama pada bahasa Inggris dan bahasa Jepang. Sebab untuk bisa menjangkau luasnya dunia, sangat dibutuhkan penguasaan bahasa asing yang baik. Dari sinilah muncul kosakata baru yang biasa disebut kosakata serapan. Kosakata serapan di Jepang sendiri disebut gairaigo. Gairaigo sendiri setiap tahunnya semakin banyak digunakan di Jepang. Kosakata yang paling banyak diserap oleh 
bahasa Jepang adalah bahasa inggris, hal ini disebabkan karena bahasa Inggris salah satu bahasa Internasional.

Pengaruh dari globalisasi membuat pemakaian gairaigo sangat mungkin akan terus meningkat karena penggunaanya yang semakin meluas baik dalam percakapan, pidato, bahasa tulis di media cetak maupun media eletronik, pada kesempatan formal dan informal. Gairaigo diserap dari bahasa asing akan cenderung dilakukan, dikarenakan ketiadaan kata dan nuansa makna yang tidak dapat dideskripsikan secara tepat dengan menggunakan bahasa Jepang. Oleh sebab itu, dengan tetap menggunakan bahasa asing tersebut nilai rasa, nuansa dan harmonisasi kata tetap terjaga. Gairaigo yang sudah digunakan oleh masyarakat Jepang ini memiliki makna, pengucapan serta penulisan yang cukup berbeda apabila dibandingkan dengan bahasa aslinya. Kata -kata yang termasuk kedalam gairaigo ini dapat dengan mudah untuk dibedakan dengan kata yang berasal dari bahasa Jepang itu sendiri. Dalam hal ini, kosakata gairaigo akan ditulis menggunakan huruf katakana.

Berikut beberapa contoh gairaigo:

- イメージ ‘imeeji’ (image) yang berasal dari bahasa Inggris

- アルバイト 'arubaito' (arbeit) dari bahasa Jerman

- クインテット’kuintetto' (quintet) dari bahasa Italia

- アルゴール ‘arukooru' (alkohol) dari bahasa arab

- コーヒー 'koohii' (koffie) dari bahasa Belanda

- アンケート ‘anketto' (enquete) dari bahasa perancis

Selain contoh gairaigo di atas, ada juga beberapa gairaigo yang disingkat seperti:

- パソコン 'pasokon' (personal computer)

- マスコミ ‘masukomi' (misscommunication)

Ada pula gairaigo yang dikombinasikan dengan bahasa Jepang, seperti:

- 消しゴム 'keshi gomu’ (eraiser)

- コピーする 'kopi- suru' (copy)

Dari beberapa contoh di atas dapat dilihat beberapa proses perubahan gairaigo dari bahasa aslinya. Proses tersebut disesuaikan dengan kaidah 
bahasa Jepang sehingga dapat digunakan dengan tepat. Gairaigo yang mengalami perubahan morfofonemis terlihat adanya penambahan fonem, penghilangan fonem dan pemanjangan fonem. Sedangkan gairaigo yang mengalami perubahan morfologis mengalami pemendekan kata, penggabungan kata, penambahan afiks dan lain-lain. Dalam penelitian ini khusus membahas proses pembentukkan gairaigo ditinjau dari segi morfologisnya. Sutedi (2003: 41) mengemukakan bahwa morfologi merupakan cabang dari linguistik yang mengkaji tentang kata dan pembentukkannya. Untuk mengetahui sebuah gairaigo mengalami proses morfologis dilihat dari asal mula kata itu diambil lalu bagaimana perubahan bentuknya setelah diserap menjadi bahasa Jepang.

Gairaigo dalam dunia pendidikan tidak jarang digunakan, terutama dalam media pembelajaran buku teks. Salah satu buku teks yang digunakan oleh pembelajar bahasa Jepang pemula di Perguruan Tinggi adalah minna no nihongo shokyu I. Buku teks ini dianggap baik karena di dalamnya telah mencakup empat keterampilan berbahasa yaitu: menyimak (kiku), berbicara (hanasu), membaca (hanasu) dan menulis (yomu). Sesuai hasil evaluasi wahyuningtias (2017:16) mengatakan empat buku teks pelajaran seri minna no nihongo ditinjau dari empat komponen (materi, keterampilan berbahasa, penyajian dan keterbacaan) berada dalam kategori baik. Gairaigo yang terdapat dalam buku teks minna no nihonggo 1, merupakan gairaigo dasar, yang pada umumnya di dominasi oleh kata benda. Dalam buku teks minna no nihongo shokyu I terdapat beberapa gairaigo yang dapat dianalisis proses pembentukkan secara morfologis. Berdasarkan latar belakang diatas penelitian ini merumuskan proses pembentukkan gairaigo secara morfologis yang terdapat dalam buku teks Minna no Nihongo shokyu I.

\section{Metode Penelitian}

Data dalam penelitian ini diambil dari buku teks minna no nihongo shokyu 1. Penelitian ini merupakan jenis penelitian deskriptif kualitatif. Moelong (2007) mengatakan bahwa penelitian kualitatif adalah penelitian 
yang datanya tidak berbentuk angka yang diperoleh dari rekaman, pengamatan, wawancara, atau bahasa tertulis. Metode yang digunakan dalam penelitian ini adalah metode deskriptif. Afurchan (2004) mengatakan metode deskriptif adalah suatu metode penelitian yang ditujukan untuk menggambarkan fenomena-fenomena yang ada, yang berlangsung pada saat ini atau saat yang lampau.

\section{Kajian Teori}

Menurut Sutedi (2003:45) sekurang-kurangnya ada 4 proses pembentukkan kata dalam bahasa Jepang, yaitu: Haseigo, fukugougo, karikomi dan toujigo. Haseigo (kata jadian) terbentuk melalui penggabungan kata dasar dengan imbuhan. Mis: penambahan sufik -na pada gairaigo dengan kelas kata adjektiva, seperti: ユニークな yuniiku na "unik". Fukugogo terbentuk sebagai hasil penggabungan beberapa morferm isi atau disebut juga dengan kata majemuk.contoh: シャープペ シル sya-pupensiru. Karikomi

merupakan akronim yang berupa suku kata (silabis) dari kosakata aslinya, contoh: テレビション terebishon menjadi terebi “televisi”. Toujigo merupakan singkatan huruf pertama yang dituangkan dalam huruf alphabet, contoh: Water Closet menjadi WC

Teori lain yang membahas tentang proses pembentukkan kata dalam bahasa Jepang juga diungkapkan oleh Tsujimura. Menurut Tsujimura (2000: 148-154), pembentukan kata dapat dilakukan dengan lima cara, yaitu: afiksasi, penggabungan (compounding), reduplikasi, pemenggalan (clipping), dan peminjaman (borrowing).

Afiksasi

Afiksasi adalah proses pembentukan atau hasil penambahan afiks pada akar, dasar, atau alas (Kridalaksana, 2008: 3). Tsujimura tidak memberikan contoh. proses afiksasi pada gairaigo. Proses afiksasi pada gairaigo salah satunya diberikan oleh Vance (1993), misalnya: prefiks zen- + chiimu 
menjadi zen-chiimu "seluruh tim"; pre m,fiks shin- + eneruji menjadi shineneruji "energi baru", dan banyak contoh lainnya.

\section{Penggabungan (compounding)}

Penggabungan disebut juga compound, adalah proses penggabungan dua atau lebih kata (Tsujimura, 2000: 154). Masih dalam Tsujimura, Shibatani menyebutkan unsur-unsur yang bisa membentuk compound adalah: a) kosakata asli bahasa Jepang (native words), mis. "aki-zora" langit musim gugur"e merupakan gabungan dari kata aki "langit" dan sora "langit" yang kemudian mengalami penyesuaian bunyi menjadi aki-zora, b) Sino dan bahasa Jepang, mis. ken-kyuu "penelitian", dan c) kombinasi antara kosakata bahasa asing (serapan) dengan native word, mis. garasumado "jendela kaca"e (garasu "kaca" diserap dari bahasa Inggris glass, dan mado "jendela" adalah kosakata asli bahasa Jepang).

\section{Reduplikasi (pengulangan)}

Kridalaksana (2010) secara umum mengelompokkan reduplikasi (pengulangan) menjadi tiga kelompok besar, yaitu: reduplikasi fonologis, reduplikasi morfemis, dan reduplikasi sintaktis. Dalam pembahasan proses morfologis yang melibatkan gairaigo sebagai leksem dasar, tidak ditemukan gairaigo yang terbentuk melalui reduplikasi dalam sumber data.

Pemendekkan kata (abreviasi)

Abreviasi merupakan proses pemenggalan satu atau beberapa bagian leksem atau kombinasi leksem sehingga terjadilah bentuk baru yang berstatus kata (Kridalaksana, 2010:159). Istilah lain untuk abreviasi adalah pemendekan, sedangkan hasil prosesnya disebut kependekan. Kridalaksana membagi bentuk kependekan menjadi lima, yaitu: singkatan, penggalan, akronim, kontraksi, dan lambang huruf (2010: 162). Menurut Anbiya (2012: 13), "Singkatan adalah bentuk yang dipendekkan, yang terdiri atas satu huruf atau lebih". Contohnya: DPR (Dewan Perwakilan Rakyat) dan dll. (dan lain-lain). Penggalan yaitu proses pemendekan yang 
mengekalkan salah satu bagian dari leksem, seperti: Prof (Profesor), $\mathrm{Bu}$ (Ibu), dan Pak (Bapak) (Kridalaksana, 2010: 162). Sedangkan akronim menurut Kridalaksana (2010: 162), merupakan proses pemendekan yang menggabungkan huruf atau suku kata atau bagian lain yang ditulis dan dilafalkan sebagai sebuah kata yang sedikit banyak memenuhi kaidah fonetik bahasa Indonesia seperti: ABRI (Angkatan Bersenjata Republik Indonesia), IKIP (Institut Keguruan dan Ilmu Pendidikan), LAN (Lembaga Administrasi Negara). Kontraksi menurut Kridalaksana (2010:162-163) yaitu proses pemendekan yang meringkaskan leksem dasar atau gabungan leksem seperti takkan (tidak akan), rudal (peluru kendali), sendratari (seni drama tari). Lambang huruf menurut Kridalaksana (2010: 163), yaitu proses pemendekan yang menghasilkan satu huruf atau lebih yang menggambarkan konsep dasar kuantitas, satuan atau unsur, seperti $\mathrm{cm}$ (centimeter), kg (kilo gram), dan g (gram).

\section{Peminjaman (borrowing)}

Tsujimura (2000: 154) menyebutkan bahwa semua kata pinjaman dapat dimunculkan sebagai kata baru dalam bahasa Jepang. Kata-kata pinjaman ini mengalami penyesuaian, seperti penyesuaian bunyi dan penyesuaian gramatikal. Penyesuaian gramatikal artinya setelah suatu kata ditetapkan sebagai kata pinjaman, maka kata tersebut akan mendapat perlakuan sama seperti kata-kata lainnya dalam bahasa Jepang, seperti dalam hal konjugasi kata kerja, kata sifat, penentuan kelas kata, juga mengalami proses-proses morfologis seperti afiksasi, abreviasi (pemendekan), dan lainlain. Sebagai contoh, kata panikuru yang berasal dari verba bahasa Inggris panic ditambahkan sufiks $-r u$ untuk menunjukkan kala non-lampau, sehingga menjadi verba bahasa Jepang panikuru. Proses tersebut mengikuti aturan verbal inflectional paradigm dalam bahasa Jepang (Tsujimura, 2000: 154).

\section{Hasil dan Pembahasan}

Dalam buku teks minna no nihongo ditemukan sebanyak 97 gairaigo. 19 gairogo terbentuk secara morfologis dan 79 gairaigo yang terbentuk 
dengan penyesuaian bunyi (terbentuk secara fonologis). Dalam sumber data, gairaigo yang terbentuk melalui proses morfologis mengalami proses : Pengimbuhan (afiksasi), penggabungan (compound) dan pemendekkan kata (abreviasi).

Proses morfologis gairaigo pada buku teks minna no nihongo shokyu 1 dapat dilihat sebagai berikut:

Pengimbuhan (afiksasi)

\section{ハンサムな hansamu na}

ハンサムな hansamu na merupakan gairaigo yang berasal dari bahasa Inggris handsome "gagah"/"tampan". Gairago ini menduduki kelas kata sifat sehingga diberi akhiran -na

\section{コピーします}

コピーします kopi-simasu bentuk biasa dari kata ini adalah コピーするkopi-suru. Gairaigo ini berasal dari bahasa Inggris copy "salin" . Gairago ini menduduki kelas kata kerja yang diikuti akhiran -suru, sehingga makna aktivitasnya lebih kuat menjadi コピーするkopi-suru “menyalin”

Penggabungan (compound)

Dalam buku teks minna nihongo shokyu 1 terdapat sekitar 10 gairaigo yang terbentuk melalui proses penggabungan, yaitu: サー プペンシル sa-pu pensiru, パワーでんき pawa-denki, アップ ルぎんこう appuru ginkou, けしゴム keshi gomu, コンピュータ ーソフト konpyu-ta- sofuto, クリズマスカード kurizumasu ka-do, ダイニングキッチン dainiggu kiccin, ホームステイ ho-mu sutei, アジアストア ajia sutoa, アアイスクリーム. Dari keseluruhan gairaigo yang terbentuk melalui penggabungan beberapa kata terdapat gabungan bahasa asing + bahasa Jepang dan bahasa asing + bahasa asing. Berikut penjelasannya: 


\section{サープペンシル sa-pu pensiru}

Gairaigo ini berasal dari bahasa Inggris sharp pencil yang terdiri dari dua gabungan kata yaitu sharp "tajam" (kata sifat) + Pencil " pensil" (kata benda). Sa-pu pensiru dalam bahasa Jepang bermakna "pensil mekanik".

\section{パワーでんき pawa- denki}

Gairaigo ini berasal dari gabungan pawa dari bahasa Inggris power "daya" ( kata benda) dan denki dari bahasa Jepang yang artinya "listrik" (kata benda). Pawa- denki artinya "daya listrik".

\section{けしゴム keshi gomu}

Gairaigo ini terbentuk dari gabungan kata keshi yang berasal dari bahasa Jepang berarti "hapus" ( kata kerja) dan kata gomu berasal dari bahasa inggris gum yang artinya "karet" (kata benda). Keshi gomu artinya "karet penghapus"

Pemendekkan kata (abreviasi)

Dari sumber data ditemukan beberapa gairaigo yang terbentuk melalui proses pemendekkan, yaitu: デパートdepa-to, テレビ terebi, パソコン pasokon, コンビニ konbini, アニメ, シヤツ syatsu, アルバイト arubaito

\section{デパートDepa-to}

Gairaigo ini berasal dari kata bahasa Inggris department store. Diserap ke dalam bahasa Jepang dengan cara karikomi. Pemendekkan dilakukan dengan cara pemenggalan suku kata dari bahasa aslinya. Suku kata yang diambil adalah department store yang dalam bahasa 
Jepangnya dibaca depa-tomento sutoa. Depa-to berarti "toko serba ada"

\section{アルバイトArubaito}

Gairaigo ini berasal dari kata bahasa Jerman nebenarbeit. Diserap ke dalam bahasa Jepang dengan cara pemendekkan yang dilakukan dengan pemenggalan suku kata dari bahasa aslinya. Suku kata yang diambil adalah nebenarbeit dalam bahasa Jepang dibaca nebenarubaito. Arubaito berarti "pekerjaan paruh waktu"

\section{コンビニ Konbini}

Gairaigo ini berasal dari kata bahasa Inggris convenience store. Diserap ke dalam bahasa Jepang dengan cara pemendekkan yang dilakukan dengan pemenggalan suku kata dari bahasa aslinya. Suku kata yang diambil adalah convenience store dalam bahasa Jepang dibaca konbinien sutoa. konbini berarti "toko swalayan"

パソコン pasokon

Gairaigo ini berasal dari kata bahasa Inggris personal computer. Diserap ke dalam bahasa Jepang dengan cara karikomi yaitu: mengambil suku kata dari bahasa aslinya. Suku kata yang diambil adalah personal computer dalam bahasa Jepang dibaca pa-sonaru konpyutaa. Pasokon berarti "komputer pribadi/laptop".

\section{Kesimpulan}

Dari hasil dan pembahasan yang telah dilakukan, maka dapat disimpulkan bahawa gairaigo yang mengalami proses morfologis dalam buku teks minna no nihongo shokyu 1 terdapat sebanyak dua puluh (20) gairaigo. Semua gairaigo tersebut terdiri dari : dua (2) gairaigo yang 
mengalami proses afiksasi, sebelas (11) gairaigo mengalami proses penggabungan (compounding) dan sebanyak delapan (8) gairaigo mengalami proses pemendekkan (abreviasi). Proses abreviasi pada gairaigo dilakukan dengan cara penggalan dan konstraksi (karikomi).

\section{Daftar Pustaka}

Anbiya, Fatya Permata. 2012. Panduan EYD Saku. Jakarta: Transmedia

Furchan. 2004. Pengantar Penelitian dalam Pendidikan. Yogyakarta:

Pustaka Pelajar Offset.

Kridalaksana, Harimukti. 2010. Pembentukan Kata dalam Bahasa

Indonesia. Jakarta: PT Gramedia.

J. Moleong. 2007. Metodologi Penelitian Kualitatif. Bandung: PT. Remaja Rosdakarya.

Sutedi, dedi . 2003. Dasar-dasar Linguistik Bahasa Jepang. Bandung: Humaniora Utama Press.

Tsujimura, Natsuko. 2000. An Introduction to Japanese Linguistics.

Oxford: Blackwell Publishers Ltd

Vance, J. Timothy. 1993. Prefiks dan Sufiks dalam Bahasa Jepang

(terjemahan). Jakarta: Kesaint Blanc

Wahyuningtias, Hani. 2016. Kualitas Buku Teks Pelajaran Bahasa Jepang Minna no Nihongo. Jakarta: Prosiding Seminar Hasil Penelitian Volume 4 no. 1. 